\title{
Modified Soil-Adjusted Vegetation Index In Multispectral Remote Sensing Data for Estimating Tree Canopy Cover Density at Rubber Plantation
}

\author{
Wenang Anurogo ${ }^{1} *$, Muhammad Zainuddin Lubis ${ }^{1}$, Mir'atul Khusna M ufida $^{2}$ \\ ${ }^{1}$ Geomatics Engineering , Politeknik Negeri Batam, Batam Riau Island Province, Indonesia, 29461. \\ ${ }^{2}$ Informatics Engineering, Politeknik Negeri Batam, Batam Riau Island Province, Indonesia, 29461.
}

* Corresponding author : wenang@polibatam.ac.id

Tel.: +6285743322991; Office: +62778-469856 ext: 2510; fax: +62778-463620

Received: Dec 08, 2017. Revised : Jan 27, 2018, Accepted: Feb 07, 2018, Published: 1 March 2018

DOI: 10.24273/jgeet.2018.3.01.1003

\begin{abstract}
Forest inventories such as tree canopy density information require a long time and high costs, especially on extensive forest coverage. Remote sensing technology that directly captures the surface vegetation character with extensive recording coverage can be used as an alternative to carrying out such inventory activities. This research aims to determine the level of vegetation canopy cover density on rubber plants that became the location of the research and know the accuracy of the resulting data. The method used in this research is a combination of remote sensing image interpretation, geographic information system, and field measurement. Information retrieval from remote sensing data is done by using ASTER data imagery. This stage includes three parts, namely: pre-field stage, field stage, and post-field stage. The pre-field stage includes the collection of data to be used (including literature studies related to the theme of the study), image processing (geometric and radiometric correction), cropping, masking, land cover classification, vegetation index transformation, and sample determination. The final result of data processing showed that the density of the vegetation canopy in the research area ranged between $7.31-12.952 \mathrm{~cm} / \mathrm{m} 2$ in each grade of vegetation density. These values indicate the range of low-class vegetation canopy cover density to high-class vegetation canopy cover density in the research area. In this research error rate or root mean square error obtained from the calculation of canopy cover density is equal to 1.89 .
\end{abstract}

Keywords: Canopy Cover Density, Remote Sensing, ASTER Imagery, Transformation Vegetation Index

\section{Introduction}

Forest is one of the commodities that greatly affect the economic development of a country. However, forests are heavily influenced by socioeconomic pressures, along with increasing human demand for processed products from forests (Anurogo \& Murti, 2013). This product can be a major forest product such as wood or forest products in the form of processed materials commonly used for industrial purposes. Part of the use of this forest is to use land from forest areas to be converted into areas considered beneficial to human civilization in the vicinity of forest areas (Diniyati \& Achmad, 2016). As a consequence of the increasing demand for forest products, there is a change of forest area into plantations and other lands. One of the many plantations in Indonesia is rubber plantation. In some parts of Indonesia, rubber crops are an important crop, in addition, can be used to obtain rubber commodities, rubber plants can also be used to meet the needs of forest supply areas.

Forest cover or forest canopy cover is the top of the vegetation that provides protection to the environment beneath it. The presence of canopy density information is important to assess as the canopy in forest cover can detect forest status indicators or interventions in forest resource management such as indications of degradation forest product quality, although forest cover classes are unchanged (Noormasari \& Murti, 2014). Forest inventories such as tree canopy density information require a long time and high costs, especially on extensive forest coverage. Remote sensing technology that directly captures the surface vegetation character with extensive recording coverage can be used as an alternative to carrying out such inventory activities (Anurogo et al., 2015; Raharjo \& Sadono, 2008). Remote sensing is a science or technology to obtain information or a natural phenomenon through an analysis of the data obtained from the recording object, area or phenomenon being studied (Danoedoro, 2012; Lubis et al., 2017). Remote sensing technology in its development has a very fast development. This is indicated in the recording system or remote sensing data collection is done by using sensing devices installed on aircraft or satellites that have undergone rapid development so as to produce 
better quality and quantity of spatial data. The application of remote sensing satellites has been able to provide data/information on land natural resources and marine resources regularly and periodically (Sari \& Lubis, 2017; Karlinasari et al., 2012). The availability of remote sensing data in digital form enables computer-based analysis in a quantitative and consistent ways. Furthermore, remote sensing data can be used as independent input for field verification. With remote sensing technology, field data retrieval can be reduced so that it will save time and cost when compared with direct measurement in the field (Anurogo et al., 2017). Remote sensing data analysis is an activity to re-recognize the appearance of objects that have been captured by the satellite-carrying sensors. The appearance of the image in the presentation of data details is influenced by the level of spatial resolution (Sukarna, 2015; Nadi and Murad, 2017; Taki et al., 2017).

MSAVI is a transformation of vegetation index developed from NDVI transformation to minimize the effect of soil reflection on NDVI. There are two basic notions of the use of the vegetation index and its development. The first assumption is the vegetation index is a multi-channel algebra combination that can produce certain information about vegetation. The second assumption is that the open ground on the image will produce an imaginary line which is then called the land line. The line is assumed as a representative line without vegetation (Anurogo et al., 2015). The transformation of the vegetation index has been developed to produce results that are sensitive to the spectral response of vegetation objects.

\section{Research Method}

This research is about estimating the density of canopy cover by using remote sensing data technology. The method used in this research is a combination of remote sensing image interpretation, geographic information system, and field measurement. Information retrieval from remote sensing data is done by using ASTER data imagery. The ASTER image data has a spatial resolution of $15 \mathrm{~m}$ on Visible Near Infra-Red channel. The channels used in this research is channel of Visible and Near Infrared (VNIR). The ASTER data image spatial resolution is shown in Table 1.

Table 1. The ASTER data image spatial resolution

\begin{tabular}{|c|c|c|c|}
\hline Type & $\begin{array}{l}\text { Number } \\
\text { of } \\
\text { Channels }\end{array}$ & Spectrum & $\begin{array}{l}\text { Ground } \\
\text { Resolution }\end{array}$ \\
\hline VNIR & 3 bands & $\begin{array}{l}0.52 \\
0.86 u m\end{array}$ & $15 \mathrm{~m}$ \\
\hline SWIR & 6 bands & $\begin{array}{l}1.60 \\
2.43 \mathrm{um}\end{array}$ & $30 m$ \\
\hline$T I R$ & 5 bands & $\begin{array}{l}8.125 \\
11.65 \mathrm{um}\end{array}$ & $90 m$ \\
\hline
\end{tabular}

Source: (Anurogo \& Murti, 2013)

The location of the research lies in Universal Transverse Mercator coordinate X: 444800,391 $Y$ : 9194335,339. The location of the research is shown in Fig 1.

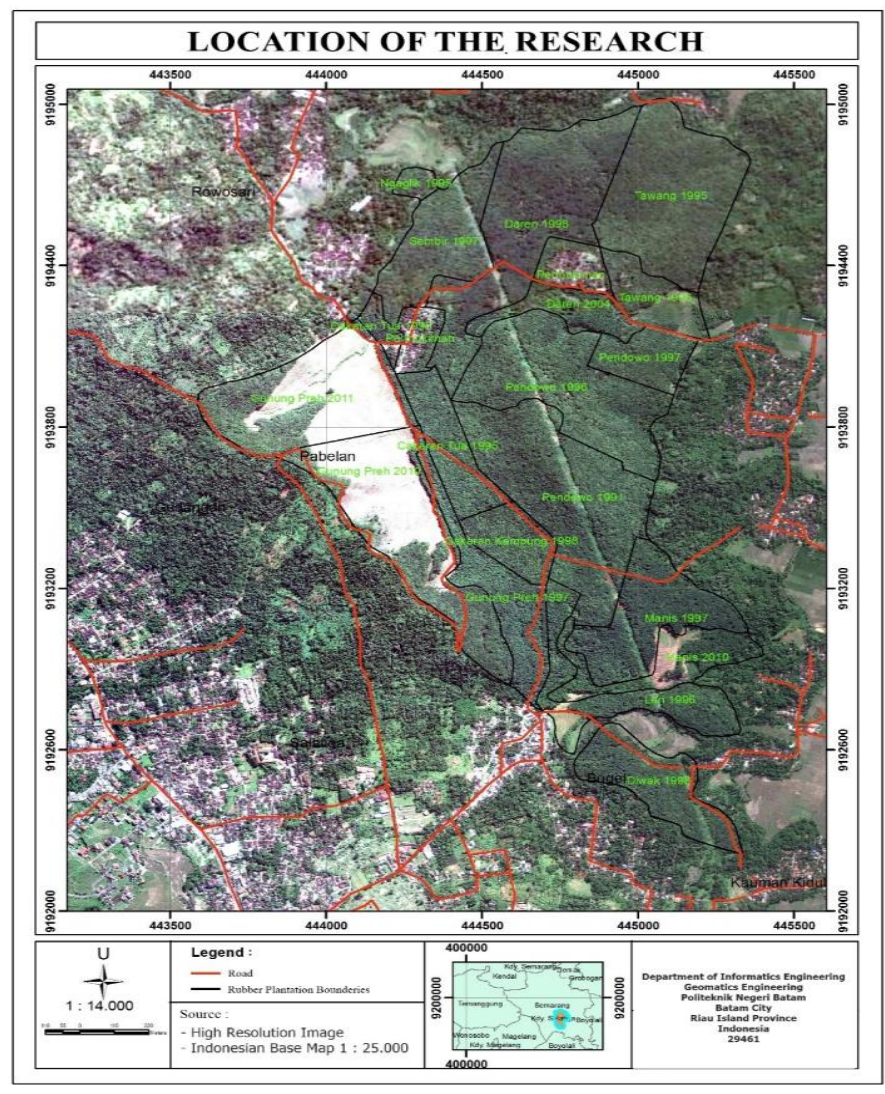

Fig 1. Location of the research area 
Stages of this research is a step that must be done to answer the purpose of research conducted. This stage includes three parts, namely: pre-field stage, field stage, and post-field stage. The pre-field stage includes the collection of data to be used (including literature studies related to the theme of the study), image processing (geometric and radiometric correction), cropping, masking, land cover classification, vegetation index transformation, and sample determination. The field stage aims to obtain information from a predetermined sample. Post-field stage is intended to process the data that has been collected, statistical analysis, test the accuracy of the results. The transformation of vegetation index used in this research is MSAVI. MSAVI is a transformation of a vegetation index developed from NDVI transformations to minimize the effect of soil reflections on NDVI.

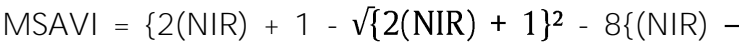
Red $\} / 2$

The transformation reduces the reflection of the soil which is the background of the vegetation where the transformation is considered suitable for the rubber plant characteristic model, where the rubber plant has a canopy which is said to be less dense so that the waves emitted from the sensor are likely to continue to the ground so that the reflection received from the sensor is partially soil reflection so as to reduce or minimize the appearance of reflections from the soil, used MSAVI transformation. To minimize this effect, the $L$ factor is given to the vegetation index formulation. The values for this $L$ factor differ for each density level, for high vegetation cover, $L$ value is 0,0 and for low vegetation cover the value of $L$ is 1.0. While for medium size vegetation, then the value of $L$ is 0.5 . The existence of this soil object will contribute as a background to the reflection of vegetation, thus affecting the value of reflected in the digital data remote sensing (Anurogo et al., 2015). The $L$ value of the factor used is 0.5 because the rate of that constant can balance the reflection of the vegetation object and the reflection of the soil that become the background of the image data recording.

The next stage is the data taking of canopy width values in the field with the transformation of the vegetation index. At this stage, measurements of trunk diameter, canopy width, and height of branch free rods were measured. In addition, field work serves as a test of accuracy, ie matching the results of interpretation of the image with the condition of the field. The accuracy test method used is with an error matrix or confusion matrix. This method uses an independent set of data that is logically more acceptable to the truth. This accuracy test includes two main things: to test the accuracy of the classification result of land cover and to find the data of vegetation density. The plot of the sample field is shown in Fig 2.

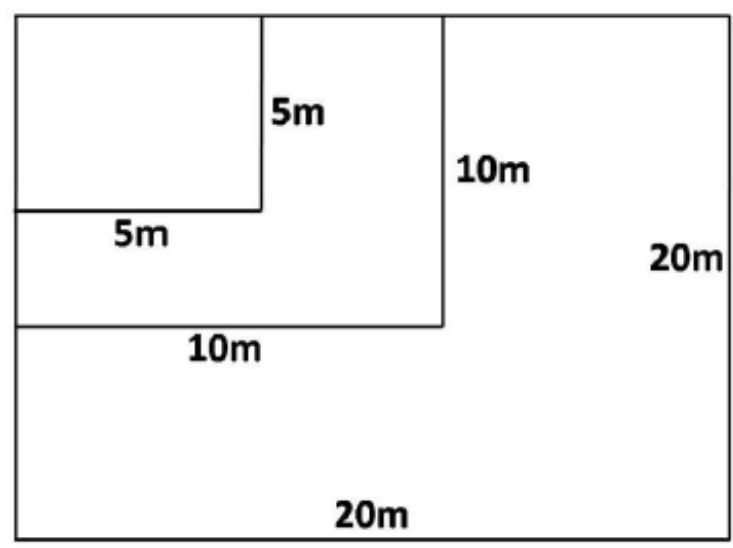

Fig 2. Plot shape in the measurement of vegetation density

The data is then later correlated with the value of each pixel image transformation to obtain a map of plant canopy density. Correlation and regression analysis is used to find the relationship between vegetation index transformation used with rubber plant density data obtained from the field so that if through the statistical approach found strong correlation result between the two variables, there is a correlation between the transformation of vegetation index which is used with rubber plant canopy density.

\section{Results and Discussion}

The first image tapping process is a land cover analysis using a multispectral classification. Multispectral classification is intended to facilitate the exploration of objects contained in images that have a similarity of spectral value. The multispectral classification used to obtain this land cover information is a supervised multispectral classification with the maximum likelihood method. The maximum likelihood method describes the pixels in the image based on the probability of a pixel to fit into a particular class. The land cover class that is sought is the class of land cover which is aimed to distinguish between vegetation object and non-vegetation object. The object of this vegetation is very prominent in ASTER composite image 321 with the dominant color of vegetation is a red color, so the result of multispectral classification can be compared with the color composite result, by comparing the pattern of color distribution in each view. The class input of this maximum likelihood classification is the training area used to collect the samples used as the basis for class classification. This training area is taken from the Region of Interest (ROI) by taking samples of each object in one scene image area of study. The selection of ROI based on the vegetation appearance of the image channel composite and based on the reflected reflectance value recorded on the image data. The boundary of the research area is the boundary of the rubber plantation. The boundary of the research was obtained by using multispectral classification data as the basis and the visual interpretation used to 
help further reinforce the boundary of the study location taken. The multispectral classification is used to isolate vegetation and non-vegetation objects. Red color indicates the vegetation area based on the value of reflect spectral while green color is non vegetation area. The multispectral classification result is shown in Fig 3.

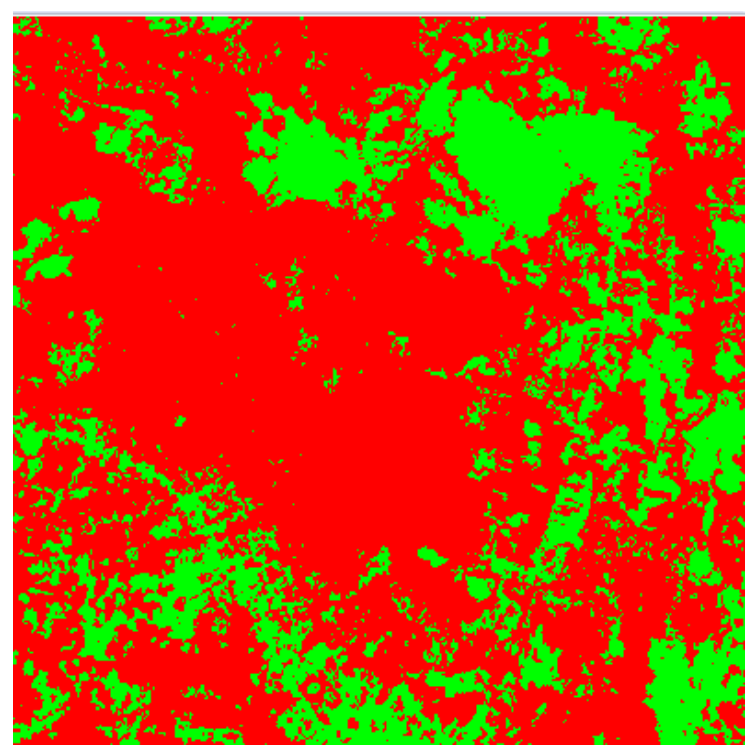

Fig 3. Multispectral classification result
After the multispectral classification, then processing the transformation of MSAVI index on vegetation classification class which will serve as one of the sampling field basis in order to obtain information of vegetation canopy density. The research mapping unit was obtained from the land cover that had been created combined with the visual interpretation result data, resulting in the boundary of the research area in the form of border of rubber plantation located in Tembir, Salatiga. The boundary of the mapping unit is then used as the basis for field sampling to retrieve information that cannot be extracted directly using remote sensing image data. Sampling is done by purposive sampling that each class is taken a sample by purpose. This field survey aims to test the level of similarity between the data we have worked on before the field and to retrieve the necessary data that cannot be known directly from remote sensing image and can only be obtained through direct measurement or retrieve existing data from the agency or service related. The assumption is that the more possible the rubber plant is at maximum productive age, then the greater the width of the existing canopy cover. Of all the areas studied, 42 samples were measured and used to represent the entire rubber plantation area. The MSAVI transformation is shown in Fig 4.

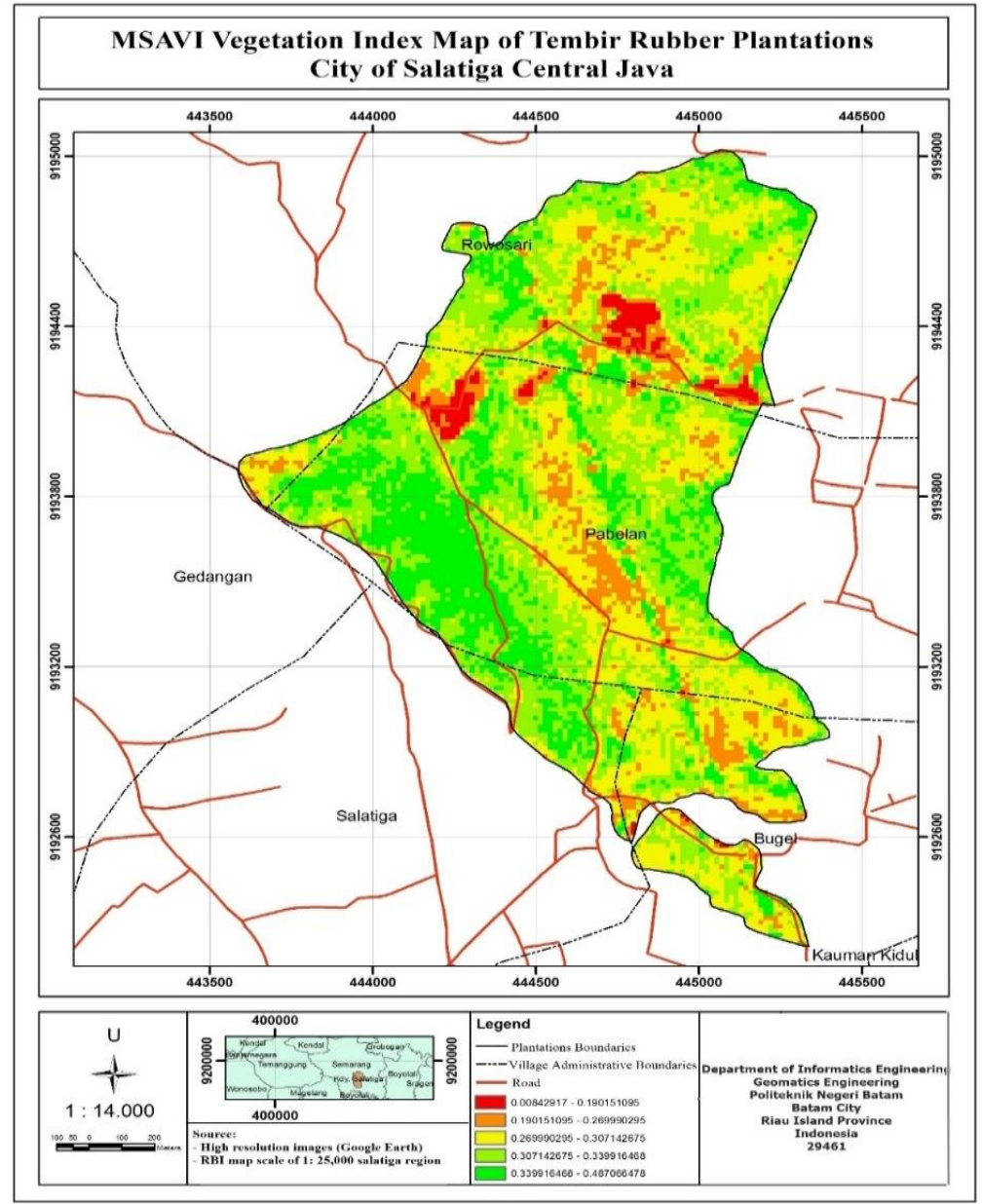

Fig 4. The MSAVI Transformation Index 
The result of transformation processing of MSAVI index shows that the range of values for the vegetation class is at $0.2699-0.467$. These values indicate the range in low-class vegetation canopy cover density to high-class vegetation canopy cover density in the research area. The transformed value range data is then correlated with data of canopy cover width obtained from the field survey. To 42 field samples then divided into two parts. The first part is a collection of samples used to create a model of regression correlation analysis between the two variables. Another sample part is to test the sample accuracy by using root mean square error (RMS e) to determine the error rate of the model. The model sample is shown in Table 2.

Table 2. Model sample between canopy and MSAVI index

\begin{tabular}{ccc}
\hline No & Canopy Cover Width $(\mathrm{cm})$ & $\begin{array}{c}\text { MSAVI } \\
\text { Index }\end{array}$ \\
\hline 1 & 8.226 & 0.363 \\
2 & 7.48 & 0.305 \\
3 & 8.96 & 0.319 \\
4 & 9.98 & 0.353 \\
5 & 6.09 & 0.271 \\
6 & 9.168 & 0.325 \\
7 & 9.33 & 0.353 \\
8 & 10.218 & 0.323 \\
9 & 8.3 & 0.343 \\
10 & 8.12 & 0.301 \\
11 & 9.78 & 0.325 \\
12 & 8.15 & 0.28 \\
13 & 6.82 & 0.258 \\
14 & 8.58 & 0.302 \\
15 & 7 & 0.231 \\
16 & 5.56 & 0.252 \\
17 & 8 & 0.28 \\
18 & 7.04 & 0.263 \\
19 & 8.04 & 0.29 \\
20 & 8.18 & 0.305 \\
\hline
\end{tabular}

The correlation model constructed is the relationship between the width of the canopy cover (density of the canopy) and the value of the transformation vegetation index used. The values of the transformation vegetation index are seen from the image of the transformation index on each sample unit, based on the vegetation index values found in each sample coordinate were taken. The result of the correlation between the index value of MSAVI vegetation index with the width of the canopy shows that the two variables are related to each other. This is indicated by the magnitude of $R^{2}$ value on the results of the correlation of both variables is 0.709 . The value is large and acceptable when viewed from the number of samples used to construct this model. The number of samples used to build this model is 20 samples, whereas in the diagram of the appendix table it is mentioned that with 20 samples, the minimum value of $R^{2}$ that can be used is 0.32 , so with the $R^{2}$ value of 0.709 , the value is quite good and the two variables are interconnected. The 2-dimensional diagram of regression is shown in Fig 5 .

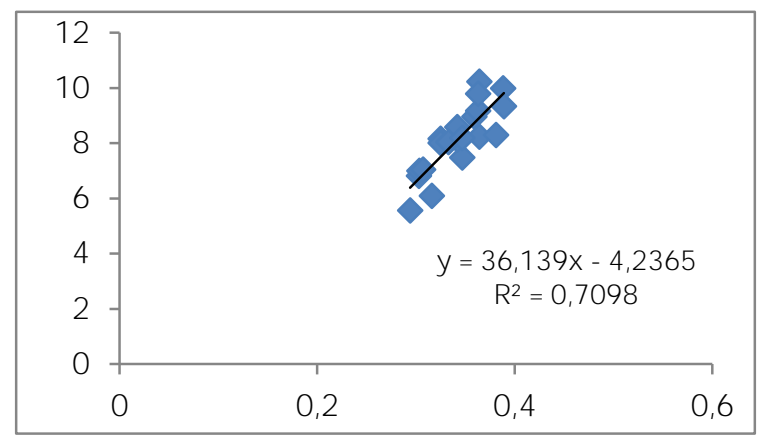

Fig 5. The 2-dimensional diagram of regression between MSAVI and Canopy

The accuracy test is performed to find out how much error rate is generated from the field data that has been taken to create the model. This accuracy test is performed on variables directly related to variables from remote sensing data to ascertain whether information derived from remote sensing data can be used. The variable that is done by the accuracy test is the canopy cover with the transformation value of the vegetation index used. The result of $Y 1$ accuracy test (canopy diameter) with MSAVI vegetation index value gives standard error value (SE) equal to 1.89. The value of SE is arguably very small for the error rate of the data used. This value indicates that at each value generated in the study, it only experienced a shift of 1.89 in the transformation model created. So, when viewed from the value, then the data canopy diameter generated ranges greater or less than the value of SE produced. From the value of the standard error that is not too large, prove that the data extraction using remote sensing image can be used as a tool in the calculation and delivery of spatial information about the density of canopy cover. The accuracy sample shown in Table 3 . The final result of data processing showed that the density of the vegetation canopy in the research area ranged between $7.31-12.952 \mathrm{~cm} / \mathrm{m}^{2}$ in each grade of vegetation density. These values indicate the range in low-class vegetation canopy cover density to high-class vegetation canopy cover density in the research area. Canopy cover density distribution of data displayed in Fig 6 . 
Table 3. The accuracy sample model

\begin{tabular}{rcccc}
\hline No & $\begin{array}{c}\text { Canopy Cover Width } \\
\text { (cm) }\end{array}$ & MSAVI Index & $\begin{array}{c}\text { y' } \\
\text { MSAVI }\end{array}$ & $\begin{array}{c}\text { y1-y1' } \\
\text { MSAVI }\end{array}$ \\
\hline $\mathbf{1}$ & 6.18 & 0.2996 & 6.588548 & 0.166911468 \\
$\mathbf{2}$ & 7.6 & 0.302 & 6.67526 & 0.855144068 \\
$\mathbf{3}$ & 8.42 & 0.342 & 8.12046 & 0.089724212 \\
$\mathbf{4}$ & 8.4 & 0.356 & 8.62628 & 0.051202638 \\
$\mathbf{5}$ & 7.825 & 0.367 & 9.02371 & 1.436905664 \\
$\mathbf{6}$ & 9.875 & 0.384 & 9.63792 & 0.056206926 \\
$\mathbf{7}$ & 6.725 & 0.338 & 7.97594 & 1.564850884 \\
$\mathbf{8}$ & 9.9 & 0.36 & 8.7708 & 1.27509264 \\
$\mathbf{9}$ & 6.945 & 0.316 & 7.18108 & 0.055733766 \\
10 & 7.5 & 0.342 & 8.12046 & 0.384970612 \\
11 & 7.7 & 0.351 & 8.44563 & 0.555964097 \\
12 & 8.325 & 0.359 & 8.73467 & 0.167829509 \\
13 & 6.875 & 0.334 & 7.83142 & 0.914739216 \\
$\mathbf{1 4}$ & 7.2 & 0.306 & 6.81978 & 0.144567248 \\
15 & 7.15 & 0.329 & 7.65077 & 0.250770593 \\
16 & 9.45 & 0.292 & 6.31396 & 9.834746882 \\
17 & 7 & 0.342 & 8.12046 & 1.255430612 \\
18 & 10.575 & 0.368 & 9.05984 & 2.295709826 \\
19 & 8.425 & 0.347 & 8.30111 & 0.015348732 \\
$\mathbf{2 0}$ & 8.425 & 0.367 & 9.02371 & 0.358453664 \\
$\mathbf{2 1}$ & 6.725 & 0.311 & 7.00043 & 0.075861685 \\
$\mathbf{2 2}$ & 9 & 0.379 & 9.45727 & 0.209095853 \\
\hline & & & & 75.67967615 \\
& & & $\mathrm{RMSe}$ & 1.898366167 \\
\hline & & & & \\
\hline
\end{tabular}

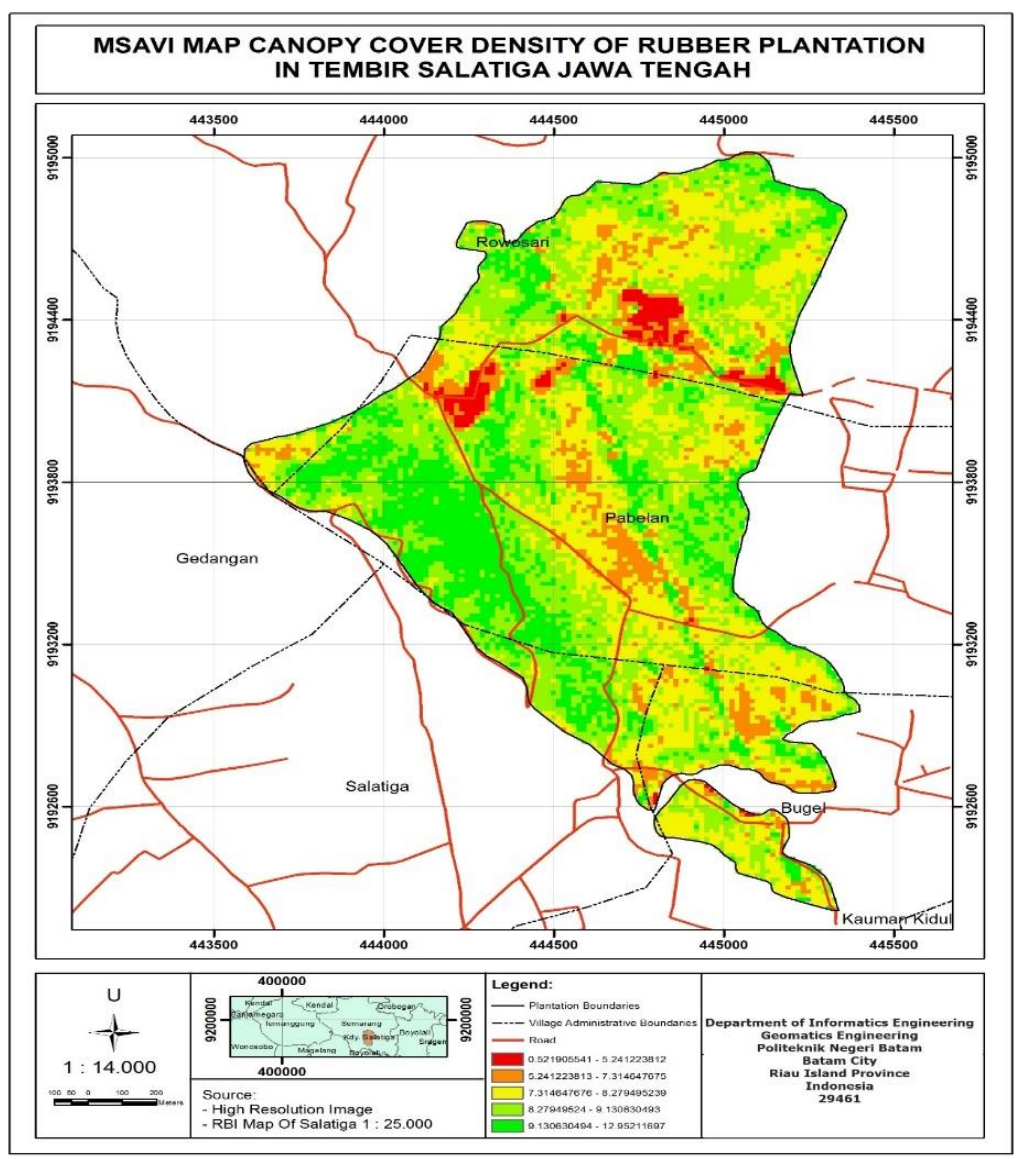

Fig 6. The Distribution of Canopy Cover Density 


\section{Conclusions}

The measurement of canopy density levels in vegetation can be calculated using aids from remote sensing image data. The use of such technology aids using a variety of approaches to get more accurate results. The final result of data processing using MSAVI transformation in measuring the density of the canopy showed that the density of the vegetation canopy in the research area ranged between $7.31-12.952 \mathrm{~cm} /$ $\mathrm{m} 2$ in each grade of vegetation density. These values indicate the range in low-class vegetation canopy cover density to high-class vegetation canopy cover density in the research area. In this research error rate or root mean square error obtained from the calculation of canopy cover density is equal to 1.89 .

\section{References}

Anurogo, W., Lubis, M.Z., Khoirunnisa, H., Pamungkas, D.S., Hanafi, A., Rizki, F., Surya, G., Situmorang, A.D.L., Timbang, D., Sihombing, P.N. and Lukitasari, C.A., 2017. A Simple Aerial Photogrammetric Mapping System Overview and Image Acquisition Using Unmanned Aerial Vehicles (UAVs). Journal of Applied Geospatial Information, 1(01), pp.11-18.

Anurogo, W., Murti, S.H. and Khakhim, N., 2015. Analisis Perubahan Hutan Mangrove Dalam Penentuan Kawasan Rehabilitasi Dan Perubahan Stok Karbon Menggunakan Data Penginderaan Jauh (Di Teluk Banten, Serang Provinsi Banten) (Doctoral dissertation, Universitas Gadjah Mada).

Anurogo, W. and Murti, S.H., Aplikasi Penginderaan Jauh Untuk Estimasi Produksi Tanaman Karet (Hevea Brasiliensis) Di Kota Salatiga, Jawa Tengah.

Danoedoro, P., 2012. Pengantar penginderaan jauh digital. Yogyakarta: Andi.

Diniyati, D. and Achmad, B., 2015. Kontribusi Pendapatan Hasil Hutan Bukan Kayu pada Usaha Hutan Rakyat Pola Agroforestri di Kabupaten Tasikmalaya. Jurnal IImu Kehutanan, 9(1), pp.23-31.

Karlinasari, L., Sabed, M., Wistara, N.J., Purwanto, A. and Wijayanto, H., 2012. Karakteristik Spektra Absorbansi NIR (Near Infra Red) Spektroskopi Kayu Acacia mangium WILLD pada 3 Umur Berbeda. Jurnal IImu Kehutanan, 6(1), pp.45-52.

Lubis, M.Z., Anggraini, K., Kausarian, H. and Pujiyati, S., 2017. Marine Seismic And Side-Scan Sonar Investigations For Seabed Identification With Sonar System. Journal of Geoscience, Engineering, Environment, and Technology, 2(2), pp.166-170.
Nadi, P.A. and Murad, A., 2017. Reviewing the use of Geographic Information System (GIS) to measure Sustainable Urban Transport performance. Journal of Geoscience, Engineering, Environment, and Technology, 2(2), pp.171-177.

Noormasari, M. and Murti, S.H., 2014. Pemanfaatan Citra Alos Avnr-2 Untuk Estimasi Produksi Tanaman Jati Dengan Menggunakan Metode Transformasi Spektral Indeks Vegetasi (Daerah Kajian: Sebagian Kabupaten Gunung Kidul) (Doctoral dissertation, Universitas Gadjah Mada).

Raharjo, J.T. and Sadono, R., 2008. Model Tajuk Jati (Tectona grandis LF) Dari Berbagai Famili Pada Uji Keturunan Umur 9 Tahun. Jurnal IImu Kehutanan, 2(2), pp.89-95.

Sari, D.P. and Lubis, M.Z., 2017. Pemanfaatan Citra Landsat 8 Untuk Memetakan Persebaran Lamun Di Wilayah Pesisir Pulau Batam. Jurnal Enggano, 2(1).

Sukarna, R.M., Perubahan Struktur dan Komposisi Hutan Rawa Gambut Menggunakan Citra Penginderaan Jauh dan Pendekatan Ekologis di Kawasan Bekas Pengembangan Lahan Gambut Provinsi Kalimantan Tengah. Jurnal IImu Kehutanan, 7(2), pp.129-146.

Taki, H.M., Maatouk, M.M.H., Qurnfulah, E.M. and Aljoufie, M.O., 2017. Planning TOD with land use and transport integration: a review. Journal of Geoscience, Engineering, Environment, and Technology, 2(1), pp.84-94. 